\title{
Pengembangan Buku Panduan Pelatihan Kesadaran Belajar dengan Menggunakan Teknik Self-Talk dalam Bimbingan Kelompok Siswa SMP
}

\author{
Dini Indah Aslami*, Irene Maya Simon, Triyono \\ Universitas Negeri Malang, Jl. Semarang No. 5 Malang, Jawa Timur, Indonesia \\ *Penulis korespondensi, Surel: diniaslami14@gmail.com
}

Paper received: 3-5-2021; revised: 24-5-2021; accepted: 28-5-2021

\begin{abstract}
Learning awareness is best for each student. Learning awareness makes learners have a distinct willingness to learn so that learning is no longer necessary. The purpose of the research and development is to produce a guidebook for learning awareness training by using self-talk technique in group guidance. This research is a type of research and development that adapts the development model from Borg and Gall. The steps taken in this research and development do not follow the overall development steps by Borg and Gall. This research and development is only up to the fifth step, namely product revision. The guidebook developed have been validated by two instrument experts, two guidance and counseling material experts and two media experts and have been tested on two prospective product users (school counselors). Based on the results of expert trials and user trials of manual products, they get an assessment that is very feasible to use.
\end{abstract}

Keywords: learning awarness; self-talk; group guidance; junior high school students

\begin{abstract}
Abstrak
Kesadaran diri dalam belajar sebaiknya dimiliki setiap pelajar. Kesadaran dalam belajar membuat peserta didik memiliki kemauan sendiri dalam belajar sehingga anak tersebut tidak perlu lagi untuk dipaksa untuk belajar.Tujuan dari penelitian dan pengembangan untuk menghasilkan panduan pelatihan kesadaran belajar siswa SMP dengan penggunaan teknik self-talk dalam bimbingan kelompok. Penelitian ini adalah jenis penelitian dan pengembangan yang mengadaptasi model pengembangan dari Borg dan Gall. Langkah-langkah yang dilakukan dalam penelitian dan pengembangan ini tidak mengikuti keseluruhan langkah pengembangan oleh Borg dan Gall. Penelitian dan pengembangan ini hanya hingga langkah kelima yaitu revisi produk. Panduan yang dikembangkan sudah divalidasi oleh dua orang ahli instrumen, dua orang ahli materi bimbingan dan konseling dan dua orang ahli media serta sudah diuji cobakan kepada calon pengguna produk yaitu dua orang konselor sekolah. Berdasarkan hasil uji coba ahli dan uji coba pengguna produk panduan mendapatkan penilaian sangat layak digunakan.
\end{abstract}

Kata kunci: kesadaran belajar; self-talk; bimbingan kelompok; siswa SMP

\section{Pendahuluan}

Belajar merupakan hak dari setiap manusia. Belajar membuat manusia mendapat pengetahuan yang dapat membantu kehidupannya kelak. Kegiatan yang disebut belajar ini memerlukan sebuah kesadaran yang dari seorang individu. "Kesadaran belajar adalah proses pembentukan kebiasaan-kebiasaan baru atau perbaikan kebiasaan yang telah ada. Tujuannya agar siswa memperoleh sikap - sikap dan kebiasaan - kebiasaan perbuatan baru yang lebih tepat dan positif dalam arti selaras dengan kebutuhan ruang dan waktu" (Syah, 2008).

Kesadaran diri dalam belajar sebaiknya dimiliki setiap pelajar. Kesadaran dalam belajar membuat peserta didik memiliki kemauan sendiri dalam belajar sehingga anak tersebut tidak perlu lagi untuk dipaksa untuk belajar. Hal ini juga didukung oleh hasil penelitian Hubungan 
Motivasi dengan Hasil Belajar IPS yang dilakukan oleh Ulfah, Santoso, Utaya (2016) , Siswa yang memiliki hasil belajar yang tinggi akan memiliki kesadaran yang tinggi pula akan pentingnya belajar. Begitu juga sebaliknya, siswa yang memiliki hasil belajar yang rendah akan memiliki kesadaran yang rendah pula.

Kesadaran diri dalam belajar sebaiknya dimiliki setiap pelajar. Kesadaran dalam belajar membuat peserta didik memiliki kemauan sendiri dalam belajar sehingga anak tersebut tidak perlu lagi untuk dipaksa untuk belajar.

Pengamatan dan wawancara kesadaran belajar siswa SMP yang ditemui di SMP Negeri 2 Ngoro Jombang sangatlah rendah. Dari tiga kelas yang masing-masing siswanya berjumlah tiga puluh orang yang menjadi objek observasi siswa tidak konsentrasi saat diberi materi oleh guru, saat pelajaran pergi ke kantin dan tidak mengumpulkan tugas tepat waktu. konselor dari sekolah ditemui belum melakukan layanan terkait dengan kesadaran belajar rendah yang dimiliki siswa.

Kesadaran belajar merupakan salah satu bentuk kesadaran diri yang harus dimiliki seorang pelajar. Kesadaran yang tinggi membuat hasil belajar dapatlah maksimal. Ada beberapa cara untuk meningkatkan kesadaran diri. Menurut De Vito (1997), mengemukakan bahwa kesadaran diri dapat ditingkatkan dengan empat cara yaitu: self-talk (berbicara dengan diri sendiri), mencari informasi tentang diri sendiri, melihat dari sisi lain, dan meningkatkan open-self (terbuka tentang diri sendiri).

Self-talk merupakan salah satu teknik yang akan membantu seseorang untuk meningkatkan kesadaran diri yang baik. Self-talk tidaklah berbicara dengan mengeluarkan kata-kata dari mulut seperti saat seseorang berbicara dengan orang lain, yang dimaksudkan disini adalah berbicara dengan pikiran-pikiran yang ada di kepala. Hackford and Schwenkmezger (dalam Permatasari, dkk., 2015) berpendapat bahwa self-talk merupakan dialog yang dimiliki seseorang mengartikan perasaan serta persepsi, mengatur sekaligus mengubah evaluasi maupun keyakinan, dan memberikan instruksi serta penguatan kepada diri sendiri.

Terdapat empat langkah untuk mengubah self-talk negatif menjadi positif. Tahap pertama yaitu mendeteksi dan mendiskusikan self-talk negatif setelah itu tahap berikutnya yaitu kedua, mengecek apa yang dimaksudkan self-talk negatif yang dialami siswa. Tahap ketiga adalah meningkatkan atau mengembangkan counters. Tahap akhir memantau kembali countering yang telah dibuat konseli serta selanjutnya mempraktikkannya. Dengan self-talk seseorang akan terdorong dengan kalimat-kalimat yang positif untuk menumbuhkan kesadaran diri.

Pelaksanaan self-talk diberikan melalui layanan bimbingan konseling salah satunya dengan bimbingan kelompok. Bimbingan kelompok merupakan proses pemberian bantuan yang diberikan individu dalam situasi kelompok. Kegiatan bimbingan kelompok yang dilakukan berupa pemberian informasi yang tepat mengenai masalah pendidikan, pekerjaan, pemahaman pribadi, penyesuaian diri dan masalah hubungan antar pribadi. Penggunaan teknik self-talk dalam bimbingan kelompok untuk meningkatkan kesadaran belajar merupakan salah satu pemberian informasi yang tepat mengenai masalah pendidikan dan pemahaman pribadi. Selain pemberian informasi pada pelatihan kesadaran belajar menggunakan teknik self-talk juga akan sampai pada tataran psikomotorik atau tindakan 
sehingga pelatihan ini dapat menghasilkan suatu perubahan perilaku, tidak hanya perolehan pengetahuan. Berdasarkan pemaparan tersebut, buku panduan ini dibuat untuk pelatihan kesadaran belajar siswa SMP dengan penggunaan teknik self-talk dalam bimbingan kelompok.

\section{Metode}

Penelitian ini memanfaatkan rancangan dari penelitian dan pengembangan atau yang disebut juga dengan Research and Development. Penelitian dan pengembangan ini dilakukan di SMP Negeri 2 Ngoro. Model pengembangan dalam penelitian ini menggunakan model prosedural yang bersifat deskriptif yang dikembangkan oleh Borg and Gall (2003) yang sudah disesuaikan dengan kebutuhan peneliti. Langkah-langkah dari penelitian dan pengembangan menggunakan model Borg and Gall, peneliti melakukan langkah tersebut sampai langkah kelima, yaitu Merevisi hasil dari uji coba (main product revision). Hasil akhir dari pengembangan yang dilakukan adalah buku panduan dan buku tugas pelatihan kesadaran belajar dengan menggunakan teknik self-talk dalam bimbingan kelompok..

\section{Hasil dan Pembahasan}

\subsection{Hasil}

\subsubsection{Pengembangan Panduan}

Penelitian dan pengembangan yang dilakukan merupakan adaptasi dari langkahlangkah pengembangan oleh Borg dan Gall. Penelitian dan pengembangan ini menghasilkan produk akhir berupa buku panduan dan buku tugas pelatihan kesadaran belajar dengan menggunakan teknik self-talk dalam bimbingan kelompok siswa SMP negeri 2 Ngoro . Berikut langkah-langkah penelitian dan pengembangan yang digunakan dalam penelitian ini.

\subsubsection{Pengumpulan Data}

Pada tahap ini peeliti melaksanakan pengumpulan data berupa wawancara dan observasi. Selain itu peneliti juga melakukan studi pustaka untuk dijadikan dasar dari pengembangan produk. Hal ini dilakukan untuk memperoleh data yang akurat dan sesuai dengan kondisi sekolah. Hasil dari kegiatan pengumpulan data digunakan sebagai dasar dari pembuatan panduan pelatihan kesadaran belajar dengan menggunakan teknik self-talk dalam bimbingan kelompok.

\subsubsection{Perencanaan}

Peneliti pada tahapan ini melakukan perencanaan terhadap produk yang akan dibuat. Perencanaan dilakukan dengan menyusun konsep dari panduan yang akan dibuat, seperti desain produk, hingga langkah-langkah. Selain menentukan langkah penelitian dalam perencanaan juga menentukan tujuan dari penelitian yang dirumuskan melalui hasil dan interpretasi analisis kebutuhan.

\subsubsection{Pengembangan Produk}

Pengembangan produk dilakukan melalui dua proses. Langkah pertama adalah menyusun prototipe buku panduan dan dilanjutkan dengan menyusun isi buku panduan. Pengembangan buku panduan didahului dengan penyusunan prototipe. Prototipe merupakan 
produk sementara dari buku panduan dan tugas yang telah dibuat serta masih memerlukan perbaikan dan revisi lebih lanjut. Setelah prototipe disusun, maka langkah atau tahap selanjutnya adalah menyusun isi buku panduan atau mendesain produk.

Buku panduan ini terdiri dari; a) kata pengantar menjabarkan tentang rasa syukur, ucapan dari peneliti atas selesainya panduan yang dibuat; b) daftar isi menjabarkan tentang isi dari panduan pelatihan kesadaran belajar siswa SMP dengan menggunakan teknik self talk dalam bimbingan kelompok; c) bagian I pendahuluan menjabarkan tentang latar belakang, tujuan pelaksanaan, sasaran pengguna, sasaran pelaksanaan, topik materi, alokasi waktu, materi self talk; d) bagian II petunjuk penggunaan panduan menjabarkan petunjuk umum dan khusus; e) bagian III prosedur pelaksanaan pelatihan menjabarkan tahap kegiatan dan RPLBK setiap pertemuan, f) daftar rujukan menjabarkan menjabarkan tentang rujukan-rujukan dalam pembuatan panduan; g) riwayat hidup menjabarkan data diri penulis. Sedangkan buku tugas berisi dari; a) kata pengantar menjabarkan tentang rasa syukur, ucapan dari peneliti atas selesainya panduan yang dibuat; b) daftar isi menjabarkan tentang isi dari panduan pelatihan kesadaran belajar siswa SMP dengan menggunakan teknik self talk dalam bimbingan kelompok; c) Petunjuk penggunaan menjabarkan aturan yang perlu diperhatikan sebelum menggunakan buku tugas, d) Self-talk menjabarkan pengenalan materi self-talk kepada siswa e) bagian I Pertemuan I menjabarkan materi perilaku belajar dan latihan; f) Pertemuan II menjabarkan materi kebiasaan belajar dan latihan; g) bagian III prosedur pelaksanaan pelatihan menjabarkan tahap kegiatan dan RPLBK setiap pertemuan, h) daftar rujukan menjabarkan menjabarkan tentang rujukan-rujukan dalam pembuatan panduan; i) riwayat hidup menjabarkan data diri penulis.

\subsubsection{Uji Coba Lapangan Awal}

Uji coba lapangan awal dilakukan oleh seseorang yang ahli dan berpengalaman untuk menilai untuk menilai produk pegembangan. Penilaian oleh seseorang yang ahli bertujuan untuk mendapatkan kritik dan saran serta masukan dari ahli sebagai bahan masukan untuk merevisi dan menyempurnakan produk yang dikembangkan. Uji coba lapangan awal ini dilakukan oleh ahli materi bimbingan dan konseling, ahli media dan konselor. Berdasarkan hasil, ahli materi bimbingan dan konseling, ahli media dan konselor diperoleh hasil penilaian ahli materi diperoleh rata-rata nilai $76 \%$ untuk buku panduan dan rata-rata nilai $76 \%$ untuk buku tugas, artinya produk memenuhi aspek kegunaan, ketepatan, kemerarikan dan kelayakan, hasil penilaian ahli media diperoleh rata-rata $97 \%$ untuk buku panduan dengan rata-rata 99\% untuk buku tugas, tugas, artinya produk memenuhi aspek kegunaan, ketepatan, kemeranrikan dan kelayakan, dan yang terakhir penilian calon pengguna diperoleh rata-rata nilai $86 \%$, tugas, artinya produk memenuhi aspek kegunaan, ketepatan, kemeranrikan dan kelayakan.

\subsubsection{Revisi Produk}

Pada tahap ini pengembang melakukan revisi dari hasil balikan yang diberikan oleh ahli pada tahap uji coba ahli. Hasil dari revisi ini nantinya akan dilakukan kembali setelah uji calon pengguna.

Tabel 1. Revisi Hasil Penilaian Uji Ahli Materi 


\begin{tabular}{clll}
\hline No & Saran dan Masukan & \multicolumn{1}{c}{ Sebelum Revisi } & \multicolumn{1}{c}{ Sesudah Revisi } \\
\hline 1 & $\begin{array}{l}\text { Pilih salah satu } \\
\text { konselor atau guru } \\
\text { BK }\end{array}$ & $\begin{array}{l}\text { Menggunakan konselor } \\
\text { dan guru bk }\end{array}$ & $\begin{array}{l}\text { Konsisten menggunakan } \\
\text { konselor }\end{array}$ \\
$\begin{array}{l}\text { Memilih metode yang } \\
\text { akan digunakan } \\
\text { dalam melaksanakan } \\
\text { bimbingan kelompok } \\
\text { Penambahan materi }\end{array}$ & Belum ada metode & $\begin{array}{l}\text { Menggunakan metode } \\
\text { ekspositori }\end{array}$ \\
4 & $\begin{array}{l}\text { Evaluasi hasil dan } \\
\text { proses belum } \\
\text { terdapat cara } \\
\text { mengolah data }\end{array}$ & $\begin{array}{l}\text { Belum tercantum } \\
\text { Belum terdapat cara } \\
\text { mengolah data dalam } \\
\text { evaluasi }\end{array}$ & $\begin{array}{l}\text { Menambah } \\
\text { data dalam evaluasi }\end{array}$ \\
\end{tabular}

Tabel 2. Revisi Hasil Penilaian Uji Ahli Media

\begin{tabular}{clcl}
\hline No & Saran dan Masukan & Sebelum Revisi & \multicolumn{1}{c}{ Sesudah Revisi } \\
\hline 1 & $\begin{array}{l}\text { Cover bisa lebih di } \\
\text { perbaiki }\end{array}$ & Cover kurang menarik & $\begin{array}{l}\text { Cover lebih banyak } \\
\text { gambar }\end{array}$ \\
2 & $\begin{array}{l}\text { Antara cover dan isi } \\
\text { berbeda backgroundnya }\end{array}$ & $\begin{array}{l}\text { Cover dan isi memiliki } \\
\text { background yang sama }\end{array}$ & $\begin{array}{l}\text { Cover dan isi memiliki } \\
\text { background yang berbeda }\end{array}$ \\
\hline
\end{tabular}

Tabel 3. Revisi Hasil Penilaian Uji Calon Pengguna

\begin{tabular}{|c|c|c|c|}
\hline No & Saran dan Masukan & Sebelum Revisi & Sesudah Revisi \\
\hline 1 & Menambah referensi & $\begin{array}{l}\text { Materi baru pertama kali } \\
\text { ketahui oleh konselor } \\
\text { sehingga konselor } \\
\text { mengharapkan materi } \\
\text { tambahan }\end{array}$ & Materi diperkaya \\
\hline 2 & $\begin{array}{l}\text { Penulisan lebih } \\
\text { diperbaiki lagi }\end{array}$ & $\begin{array}{l}\text { Terdapat kesalahan ketik } \\
\text { pada kata }\end{array}$ & $\begin{array}{l}\text { Kesalahan sudah } \\
\text { diperbaiki }\end{array}$ \\
\hline
\end{tabular}

\subsection{Pembahasan}

Produk dalam penelitian dan pengembangan yang dikembangkan berupa buku panduan dan buku tugas pelatihan kesadaran belajar menggunakan teknik self-talk dalam bimbingan kelompok. Selain buku panduan produk penelitian dan pengembangan dilakukan menghasilkan buku tugas. Model penelitian pengembangan ini mengadaptasi model pengembangan Borg \& Gall. Secara teoritis, model pengembangan Borg \& Gall (2003), terdiri dari sepuluh langkah. Pada penelitian ini disesuaikan dengan kebutuhan penelitian sehingga diselesaikan sampai 5 langkah yaitu pengumpulan data, perencanaan. pengembangan produk, uji coba lapangan awal dan revisi produk

Studi pendahuluan berupa wawancara dan observasi dilakukan guna mengetahui kebutuhan siswa sehingga dapat mengembangkan produk sesuai dengan metode dan teknik. Hal ini sejalan dengan yang dikemukakan oleh Dick dan Carey (dalam Sitanggang 2013) bahwa peneliti dapat melakukan kesalahan dalam asumsi apabila karakteristik siswa diambil tanpa mengadakan observasi atau wawancara. SMP Negeri 2 Ngoro memiliki hasil bahwa siswa SMP 
Negeri 2 Ngoro memiliki rata-rata hasil belajar yang rendah dalam mata pelajaran. Hasil belajar memiliki korelasi positif dengan kesadaran belajar. Maka diketahui bahwa SMP Negeri 2 Ngoro memiliki kesadaran belajar yang rendah.

Dalam proses pengembangan produk dilakukan uji lapangan awal sebanyak tiga kali yaitu uji ahli media, materi dan uji calon pengguna. Uji validitas dilaksanakan untuk mengukur terhadap kelayakan dan keberterimaan produk yang dibuat dari aspek penilaian ketepatan, kegunaan, kemenarikan, dan kelayakan produk. Pelaksanaan uji validasi oleh ahli dan uji coba pengguna sangat penting dalam proses penelitian dan pengembangan, hal ini sejalan dengan pendapat Sukmadinata (2016) yang mengatakan bahwa uji validasi oleh ahli sangat penting dilakukan untuk mengetahui kelayakan konsep dasar atau teori yang mendasari penelitian dan uji coba pengguna digunakan untuk mengetahui kelayakan secara praktis.

Buku panduan ini terdiri dari; a) kata pengantar menjabarkan tentang rasa syukur, ucapan dari peneliti atas selesainya panduan yang dibuat; b) daftar isi menjabarkan tentang isi dari panduan pelatihan kesadaran belajar siswa SMP dengan menggunakan teknik self talk dalam bimbingan kelompok; c) bagian I pendahuluan menjabarkan tentang latar belakang, tujuan pelaksanaan, sasaran pengguna, sasaran pelaksanaan, topik materi, alokasi waktu, materi self talk; d) bagian II petunjuk penggunaan panduan menjabarkan petunjuk umum dan khusus; e) bagian III prosedur pelaksanaan pelatihan menjabarkan tahap kegiatan dan RPLBK setiap pertemuan, f) daftar rujukan menjabarkan menjabarkan tentang rujukan-rujukan dalam pembuatan panduan; g) riwayat hidup menjabarkan data diri penulis. Sedangkan buku tugas berisi dari; a) kata pengantar menjabarkan tentang rasa syukur, ucapan dari peneliti atas selesainya panduan yang dibuat; b) daftar isi menjabarkan tentang isi dari panduan pelatihan kesadaran belajar siswa SMP dengan menggunakan teknik self talk dalam bimbingan kelompok; c) Petunjuk penggunaan menjabarkan aturan yang perlu diperhatikan sebelum menggunakan buku tugas, d) Self-talk menjabarkan pengenalan materi self-talk kepada siswa e) bagian I Pertemuan I menjabarkan materi perilaku belajar dan latihan; f) Pertemuan II menjabarkan materi kebiasaan belajar dan latihan; g) bagian III prosedur pelaksanaan pelatihan menjabarkan tahap kegiatan dan RPLBK setiap pertemuan, h) daftar rujukan menjabarkan menjabarkan tentang rujukan-rujukan dalam pembuatan panduan; i) riwayat hidup menjabarkan data diri penulis.

Dalam proses pengembangan produk berupa panduan melalui tiga uji validasi terhadap kelayakan dan keberterimaan produk yang dibuat dari aspek penilaian ketepatan, kegunaan, kemenarikan, dan kemudahan produk. Pelaksanaan uji validasi oleh ahli dan uji coba pengguna sangat penting dalam proses penelitian dan pengembangan, hal ini sejalan dengan pendapat Sukmadinata (2016) yang mengatakan bahwa uji validasi oleh ahli sangat penting dilakukan untuk mengetahui kelayakan konsep dasar atau teori yang mendasari penelitian dan uji coba pengguna digunakan untuk mengetahui kelayakan secara praktis.

Penilaian ahli materi bimbingan dan konseling dilakukan oleh dua dosen ahli materi bimbingan konseling yang berasal dari dosen Bimbingan dan Konseling Universitas Negeri Malang. penilaian dari ahli materi bimbingan dan konseling mendapat hasil sangat layak digunakan karena dalam penyusunan produk berupa panduan pelaksanaan layanan bimbingan kelompok, peneliti menyusun berdasarkan karakteristik dan kebutuhan siswa akan panduan. Penilaian ahli media dilakukan oleh dosen Teknologi Pendidikan Universitas Negeri Malang. Sedangkan untuk uji calon pengguna dilakukan oleh konselor dari SMP Negeri 2 Ngoro. 
Penilaian dari ahli materi, ahli media dan uji calon pengguna bimbingan dan konseling mendapatkan hasil sangat layak digunakan. Aspek yang menjadi penilaian adalah aspek keberterimaan produk yaitu aspek ketepatan, aspek kegunaan, aspek kelayakan, dan aspek kemenarikan.

Peneliti melakukan revisi sesuai dengan saran dan masukan oleh ahli instrumen, ahli materi, ahli media, dan calon pengguna produk. Hasil dari revisi adalah produk akhir penelitian dan pengembangan in yaitu "Panduan Pelatihan Kesadaran Belajar Siswa SMP dengan Menggunakan Teknik Self-Talk dalam Bimbingan Kelompok" dan "Buku Tugas Pelatihan Kesadaran Belajar Siswa SMP dengan Menggunakan Teknik Self-Talk dalam Bimbingan Kelompok". Produk ini diharapkan dapat membantu konselor dalam memberikan layanan bimbingan kelompok untuk mengurangi kecenderungan menyontek siswa SMP.

\section{Simpulan}

Berdasarkan hasil penelitian dan pengembangan ini dapat disimpulkan bahwa penelitian dan pengembangan ini menghasilkan produk berupa "Panduan Pelatihan Kesadaran Belajar Siswa SMP dengan Menggunakan Teknik Self-Talk dalam Bimbingan Kelompok". Langkah yang dilakukan pada penelitian dan pengembangan ini adalah pengumpulan data, perencanaan produk, pengembangan produk, uji awal lapangan dan revisi produk. Panduan yang dikembangakan melalui tiga uji validasi terhadap kelayakan dan keberterimaan produk yang dibuat dari aspek penilaian ketepatan, kegunaan, kemenarikan, dan kemudahan produk. Demikian produk buku panduan dan buku tugas pelatihan kesadaran belajar dengan menggunakan teknik self-talk dalam bimbingan kelompok layak digunakan oleh konselor.

\section{Daftar Rujukan}

Borg, W. R. \& Gall, M. D. (2003). Educational Research: An Introduction 4 th Edition. London: Longman Inc.

Muhibbi, S. (2008). Psikologi Belajar. Jakarta: PT Raja Grafindo Persada.

Permatasari, Y. S. D. (2014). Efektivitas Pelatihan Self-talk Untuk Meningkatkan Efikasi Diri dan Penampilan Atlet Kumite Karate UNS. Skripsi. Surakarta : Universitas Sebelas Maret

Sitanggang, N. \& Abdul H. S. (2013). Studi Karakeristik Siswa SLTA di Kota Medan. Jurnal Teknologi Pendidikan, 6(2), 187.

Sukmadinat, N. S. (2009). Metode Penelitian Pendidikan. Bandung: Remaja Rosdakarya

Ulfah, S. U. (2016). Hubungan Motivasi dengan Hasil Belajar IPS. Tesis. Malang: Universitas Negeri Malang 